\author{
Rajib Hasan* and Harun Or Rashid \\ Department of Zoology, Biological sciences, \\ University of Dhaka, Dhaka 1000, Bangladesh \\ Dates: Received: 13 May, 2016; Accepted: 26 May, \\ 2016; Published: 27 May, 2016 \\ *Corresponding author: Rajib Hasan, Department \\ of Zoology, Biological sciences, University \\ of Dhaka, Dhaka 1000, Bangladesh, E-mail; \\ rajib.hasan4646@gmail.com \\ www.peertechz.com \\ ISSN: 2455-8400
}

Keywords: Availability assessment; Habitat;

Biometric data; Correlation

\author{
Research Article
}

\section{A Study and Availability Assessment of Freshwater Crabs in the Hill Streams of Bangladesh}

\section{Introduction}

Bangladesh is a country which is mostlylow in elevation and the hill areas occur in the Khagrachari, Rangamati, Bandarban, Chittagong, Cox's Bazar, Mymensingh, Netrokona, Sylhet, Moulavibazar and Habiganj districts. These regions include a remarkable area of hilly rivers, lakes and streams and waterfalls that are identified to be an excellent playground of biodiversity. Various small and moderately large streams have been found all over the country which are very rich of ecologically important species. So streams of hilly areas are predicted to be the biodiversity hot spots in the country containing a high diversity of crab species that have yet to discover.

Freshwater crabs are found throughout the tropical and sub-tropical regions of the world. They live in a wide range of water bodies, from fast-flowing rivers to swamps, as well as in tree boles or caves. The majority of species are narrow endemics, occurring in only a small geographical area. This is at least partly attributable to their poor dispersal abilities and low fecundity [1] and to habitat fragmentation caused by the world's human population [2]. Freshwater crabs of Bangladesh can distinguished from false crabs by not having 5th pair of periopods totally or partly having concealed beneath the carapace, the antennae were always placed between the inner margin of orbit and fused pterygostomial region with endestome [3]. In most decapods, the gonopores (sexual openings) are found on the legs. However, since crabs use the first two pairs of pleopods (abdominal appendages) for sperm transfer, this arrangement has changed. As the male abdomen evolved into a narrower shape, the gonopores have moved towards the midline, away from the legs, and onto the sternum [4]. The hilly crab faunas of Bangladesh have never been broadly surveyed by researchers. It is necessary to know the biodiversity of freshwater crabs in hilly region of Bangladesh for conservation purpose. So the present study was focused to identify crab species in the selected waterfalls, rivers and streams in the hilly areas as well as to assess the status and diversity of crabs in relation to their habitats.

\section{Materials and Methods \\ Study sites and period}

The research was conducted in eight selected sites of three hilly districts of Bangladesh such as Sangu River in Bandarban, Shailopropat Waterfall in Bandarban, Rijuk Waterfall in Bandarban, Boga Lake in Bandarban, Himchori in Cox's Bazar, Barachara in Cox's Bazar, Kudung Cave in Cox's Bazar and Madhobkunda Waterfall in Moulvibazar (Figure 1). The study was conducted from January 2012 to December 2012 followed by the various seasons of Bangladesh with four times of Crabs collection.

\section{Collection and preservation of specimens}

Crab specimens were collected by the help of cast net (Khepla Jal), seine net, push net, dip net, and trap from above mentioned areas. After collecting the crabs, photographs were taken immediately and preserved in the plastic container with $4 \%$ alcohol. The specimens were finally preserved in $5-10 \%$ formalin in plastic container. About 100 specimens were collected from all the areas and 30 matured or adult specimens were chosen for morphometric and meristic study.

\section{Crabs identification}

All the specimens were measured carefully at the Laboratory and also were identified by using the crab identifying keys $[5,6]$, the guidelines and descriptions [7,8], were also used for crab identification.

\section{Measurement}

All morphometric measurements were taken by using scale, tape and 'Vernier Slide Calipers'. The color and presence or absence of setae noted in live condition. Body length, width, depth were measured by 


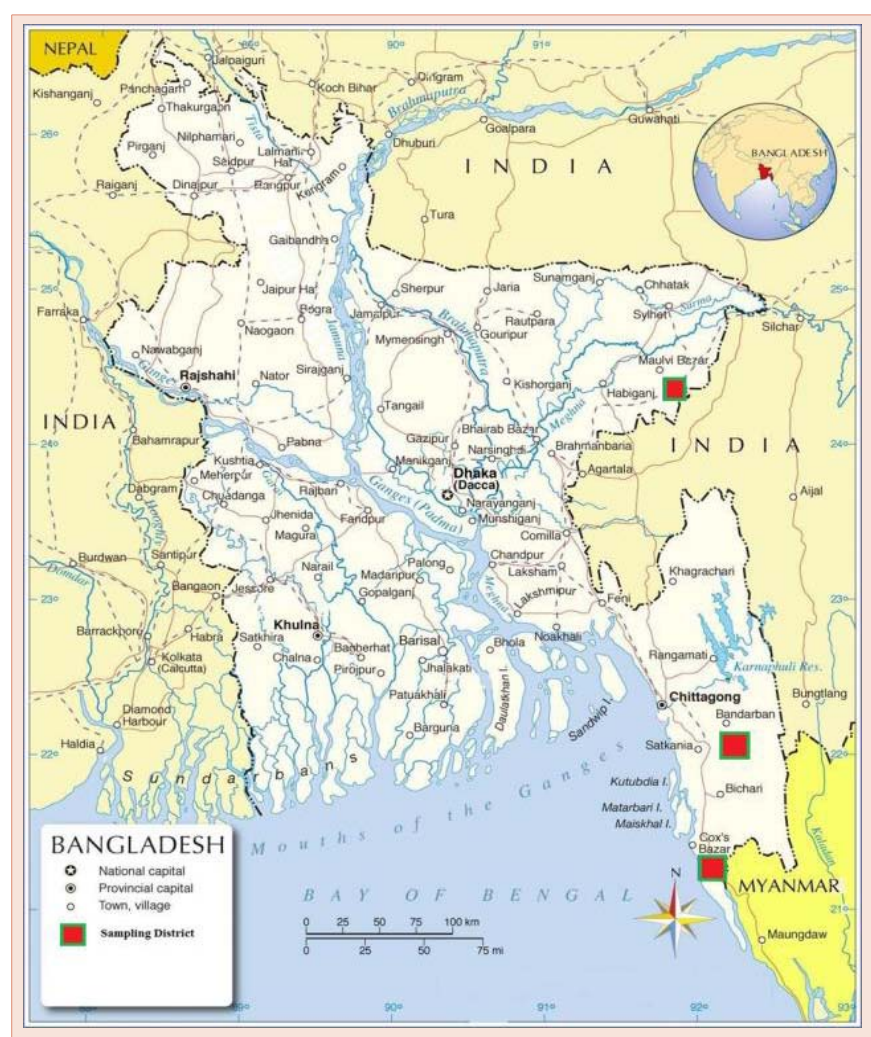

Figure 1: Map showing the geographic location of three sampling hill stream districts of Bangladesh (Bandarban, Cox's Bazar and Moulvibazar).

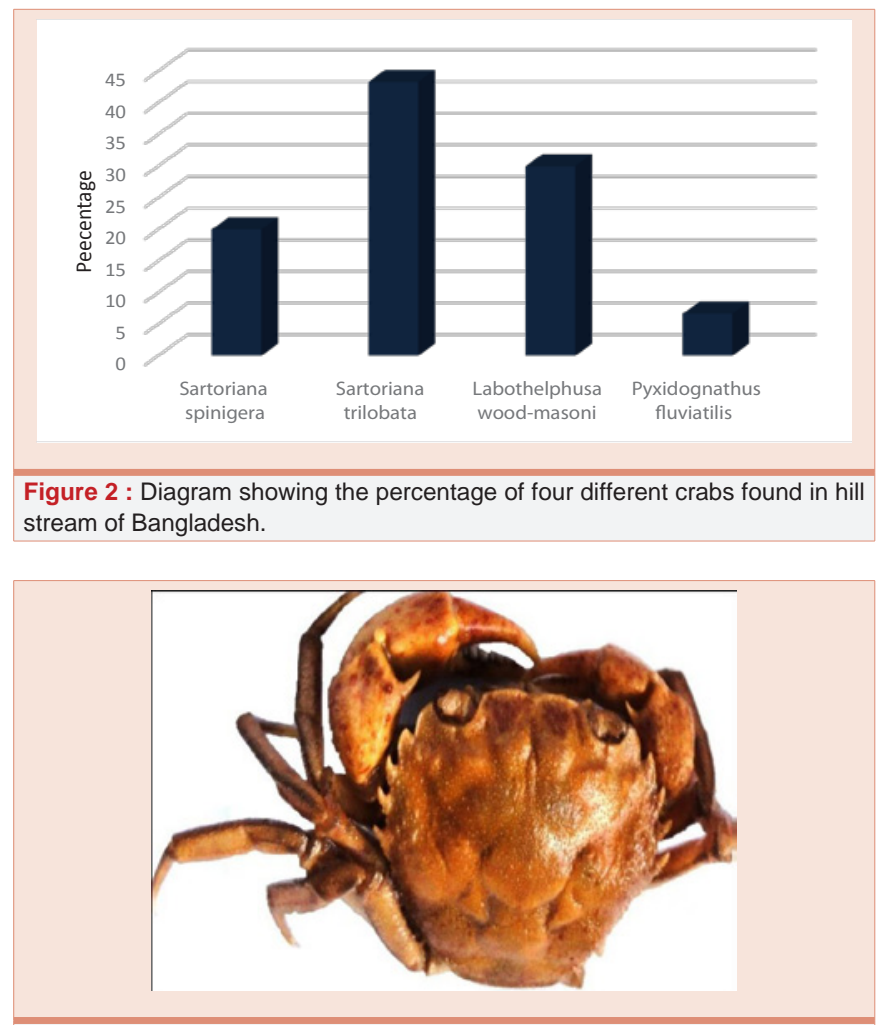

Figure 3 : Labothelphusa wood-masoni.

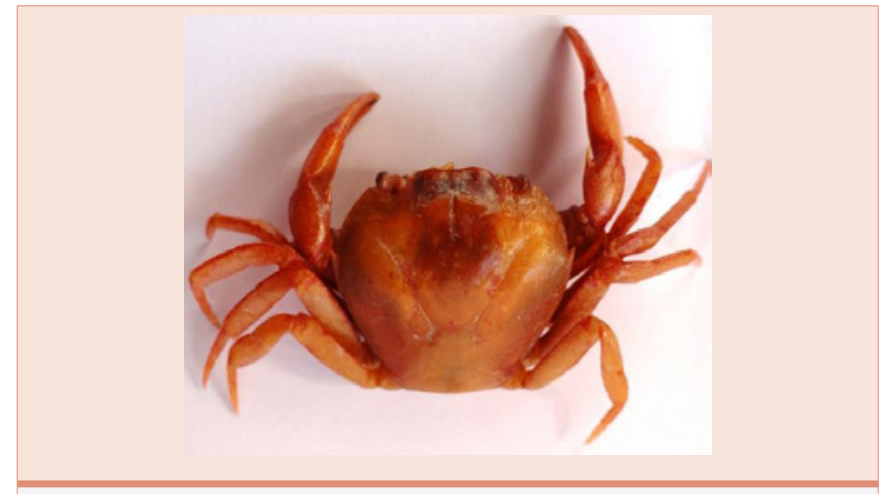

Figure 4 : Sartoriana spinigera.

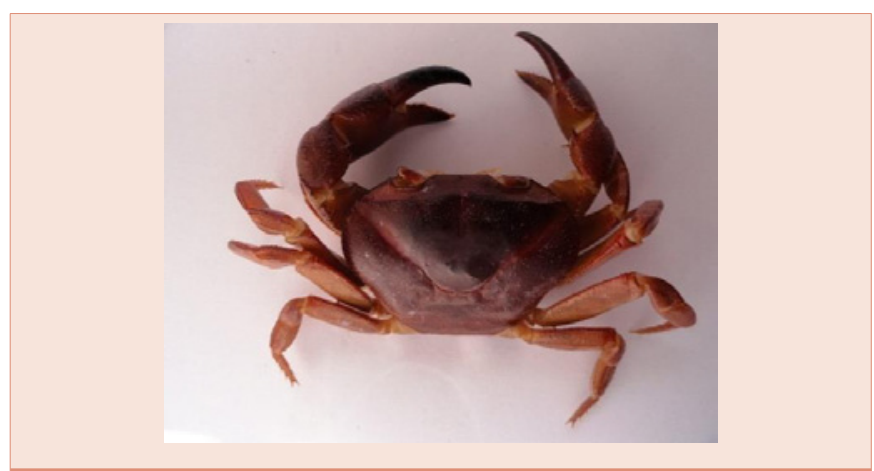

Figure 5 : Sartoriana trilobata.

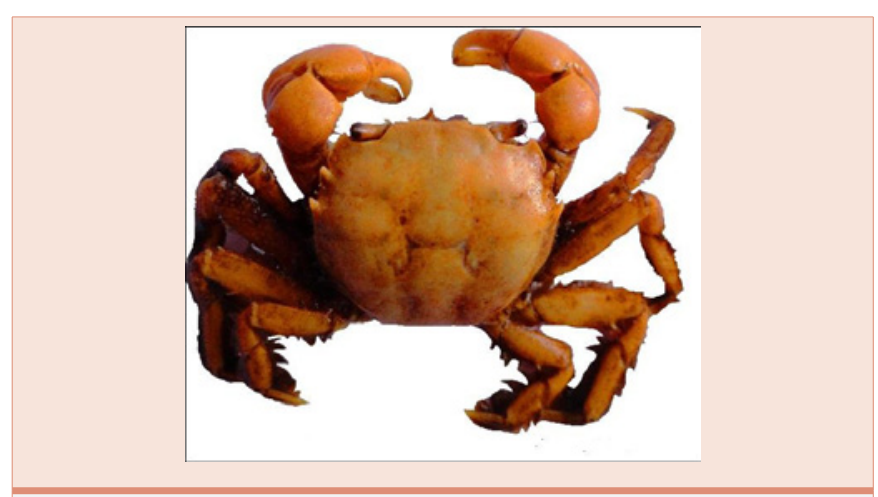

Figure 6 : Pyxidognathus fluviatilis.

slide calipers and scale. The units of the measurement were taken in $\mathrm{cm}$. The selected morphometric or morphological characteristics for identifications of specimens were taken from the fresh and preserved specimens.

\section{Statistical analysis}

To estimate the mean value and standard deviation as well as to determine the correlation among carapace length (CL), carapace width (CW), data were subsequently analyzed. Correlation was calculated by using Pearson correlation equation

$$
r=\frac{1}{n-1} \sum\left[\frac{\left(x_{i}-\bar{X}\right)}{s_{x}} \times \frac{\left(y_{i}-\bar{Y}\right)}{s_{y}}\right]
$$


Where Carapace length $X$ represents the values of independent variable and Carapace width $Y$ represents the values of dependent variables. $\bar{X}$ And $\bar{Y}$ denotes the average values.

The value of $r$ ranges between +1 and -1 :

- $\quad \mathrm{r}>0$ indicates a positive relationship of $X$ and $Y$ : as one gets larger, the other gets larger.

- $\mathrm{r}<0$ indicates a negative relationship: as one gets larger, the other gets smaller.

- $\mathrm{r}=0$ indicates no relationship

However if two variables are positively associated, then positive values of $\left(x_{i}-\bar{X}\right)$ will match up with positive values $\left(y_{i}-\bar{Y}\right)$, and negative values with negative values. The sum of $\left(x_{i}-\bar{X}\right)\left(y_{i}-\bar{Y}\right)$ will produce a positive $r$. In a negative relationship, positive values of $\left(x_{i}-\bar{X}\right)$ will match up with negative values of $\left(y_{i}-\bar{Y}\right)$, and vice versa. Then the sum of $\left(x_{i}-\bar{X}\right)\left(y_{i}-\bar{Y}\right)$, and $\mathrm{r}$, will be negative. If we calculate the Pearson correlation of $\mathrm{X}$ with itself, the result will be 1 .

If there is no association between $X$ and $Y$, there will be no systematic relationship between $\left(x_{i}-\bar{X}\right)$ and $\left(y_{i}-\bar{Y}\right)$. Therefore the positive values of one will match up with positive and negative values of the other randomly, and the same with negative values of the first variable. Therefore when we take the sum of $\left(x_{i}-\bar{X}\right)\left(y_{i}-\bar{Y}\right)$ , all these positive and negative results will tend to cancel each other out, making $r$ close to 0 .

\section{Results and Discussion}

The present study recorded total 4 species of crabs from the studied hill streams area. They are Sartoriana spinigera (WoodMason, 1871), Sartoriana trilobata (Alcock, 1909), Labothelphusa wood-masoni (Rathbun, 1905) and Pyxidognathus fluviatilis (Alcock, 1900). The S. spinigera, S. trilobata and Labothelphusa wood-masoni belongs to the family Potamidae and P. fluviatilis is under the family Grapsidae.

The greatest percentage of crabs found in hill streams was Sartoriana trilobata and which was $43.33 \%$ and dominant species in the hill streams of Bangladesh. The lowest abundance recorded was $6.67 \%$ for Pyxidognathus fluviatilis of the total specimens. Also the figure shows that Labothelphusa wood-masoni was 30\% and Sartoriana spinigera was $20 \%$ of the studied specimens. (Figure 2).

S. spinigera (Figure 4), and S. trilobata (Figure 5), are closely related species under same genus. There are some dissimilarities present in their morphology; S. trilobata is more robust than

\begin{tabular}{|c|c|c|c|c|c|c|c|c|c|}
\hline \multirow{3}{*}{ Family } & \multirow{3}{*}{ Species } & \multicolumn{8}{|c|}{ Place of occurrence } \\
\hline & & \multicolumn{4}{|c|}{ Bandarban } & \multicolumn{3}{|c|}{ Cox's Bazar } & \multirow{2}{*}{$\begin{array}{l}\text { Moulavibazar } \\
\text { Madhabkunda } \\
\text { Waterfall }\end{array}$} \\
\hline & & $\begin{array}{l}\text { Sangu } \\
\text { River }\end{array}$ & $\begin{array}{l}\text { Shailopropat } \\
\text { waterfall }\end{array}$ & $\begin{array}{l}\text { Rijuk } \\
\text { Waterfall }\end{array}$ & $\begin{array}{l}\text { Boga } \\
\text { Lake }\end{array}$ & Himchori & Barachara & $\begin{array}{l}\text { Kudung } \\
\text { Cave }\end{array}$ & \\
\hline \multirow[b]{3}{*}{ Potamidae } & Sartoriana spinigera & - & - & - & - & + & - & + & - \\
\hline & Sartoriana trilobata & - & - & - & + & + & + & - & + \\
\hline & $\begin{array}{l}\text { Labothelphusa wood- } \\
\text { masoni }\end{array}$ & - & + & - & - & + & + & - & + \\
\hline Grapsidae & $\begin{array}{l}\text { Pyxidognathus } \\
\text { fluviatilis }\end{array}$ & + & - & + & - & - & - & - & - \\
\hline
\end{tabular}

Table 2: Habitat diversity of the selected study sites of hill streams.

\begin{tabular}{|c|c|c|}
\hline Sampling site & GPS coordinates and elevation & Habitat \\
\hline Sangu River & $\begin{array}{l}12^{\circ} 10^{\prime} 58.00^{\prime \prime} \mathrm{N}, 92^{\circ} 13^{\prime} 54.00^{\prime \prime} \mathrm{E} \\
\text { Elevation: } 56 \mathrm{ft} .\end{array}$ & $\begin{array}{l}\text { Silted with sand and pebbles. } \\
\text { Turbid flowing water. }\end{array}$ \\
\hline Shailopropat Waterfall & $\begin{array}{l}22^{\circ} 09^{\prime} 05.34^{\prime \prime} \mathrm{N}, 92^{\circ} 12^{\prime} 59.00^{\prime \prime} \mathrm{E} . \\
\text { Elevation: } 303 \mathrm{ft} .\end{array}$ & Rocky with boulders in clear cold running water. \\
\hline Rijuk Waterfall & $\begin{array}{l}22^{\circ} 00^{\prime} 53.85^{\prime \prime} \mathrm{N}, 92^{\circ} 24^{\prime} 07.42^{\prime \prime} \mathrm{E} . \\
\text { Elevation: } 127 \mathrm{ft} .\end{array}$ & $\begin{array}{l}\text { Rocky with Boulders, cobbles and sand in clear } \\
\text { cold water pool under a large fall. }\end{array}$ \\
\hline Boga Lake & $\begin{array}{l}21^{\circ} 58^{\prime} 49^{\prime \prime} \mathrm{N}, 92^{\circ} 28^{\prime} 11^{\prime \prime} \mathrm{E} . \\
\text { Elevation: } 1216 \mathrm{ft} .\end{array}$ & Rock stone in clear cold water. \\
\hline Himchori & $\begin{array}{l}21^{\circ} 21^{\prime} 18.36 " \mathrm{~N}, 92^{\circ} 01^{\prime} 31.68 " \mathrm{E} \\
\text { Elevation: } 93 \mathrm{ft} .\end{array}$ & $\begin{array}{l}\text { Cobble and gravelly bottom in a clear cold water } \\
\text { small pool at the base of a waterfall. }\end{array}$ \\
\hline Barachara hill stream & $\begin{array}{l}21^{\circ} 23^{\prime} 45.82^{\prime \prime} \mathrm{N}, 92^{\circ} 00^{\prime} 02.39^{\prime \prime} \mathrm{E} \\
\text { Elevation: } 32 \mathrm{ft} .\end{array}$ & $\begin{array}{l}\text { Sandy-clay with cobbles in a muddy water } \\
\text { stream. }\end{array}$ \\
\hline Kudung Cave & $\begin{array}{l}21^{\circ} 05^{\prime} 31.8^{\prime \prime} \mathrm{N}, 92^{\circ} 10^{\prime} 10.08^{\prime \prime} \mathrm{E} . \\
\text { Elevation: } 70 \mathrm{ft} .\end{array}$ & $\begin{array}{l}\text { Rocky hill forms a cave pool with sandy-clay } \\
\text { bottom. }\end{array}$ \\
\hline Madhabkunda Waterfall & 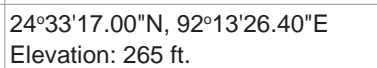 & $\begin{array}{l}\text { Rocky with Boulders, cobbles and sand in clear } \\
\text { cold water pool under a large fall. }\end{array}$ \\
\hline
\end{tabular}


Sartoriana spinigera and carapace of $S$. spinigera having only one antero-lateral spine which is absent in S. trilobata. Labothelphusa wood-masoni (Figure 3), differs from congeners by a combination of following characters: having 4 spines on antero-lateral side, cheliped equal in both sexes. Pyxidognathus fluviatilis (Figure 6), is clearly remarked by having some characteristics: antero-lateral margin having two spines ( 3 when eye groove consider as spine), upper and lower margin of propodus and dactylus having setae. They are found in freshwater ecosystem of Rijuk Waterfall and Sangu River.

The habitat of the crabs in the study sides are greatly varied from transparent clear water to turbid flowing water. The water qualities were measured and it was fine according to the accepted standard. The basic water qualities of seven sites such water temperature 20$28^{\circ} \mathrm{C}$, $\mathrm{pH}$ was 6.5-6.7, Total dissolved solids (TDS) was 225-227 ( $\left.\mu \mathrm{s}\right)$ and dissolved oxygen (DO) $10-12.4 \mathrm{mg} / \mathrm{L}$. Water was slightly turbid and acidic and $\mathrm{pH}$ near 4 at the Kudung cave. In winter clear water flows and in rainy season turbid water flows in Sangu River. Rock stones dominated the core gene of the soil at Boga Lake which is composed of small and hard rocks. The water color of this lake is blue-green and it is important habitat of freshwater organisms. The streams of Barachara were mostly shallow but deep in some areas and the water was crystal clear (Tables 1,2).

Biometrical study such as Carapace length and Width,Abdominal length, Telson length, Merus length, Carpal length and Palm length of 4 studied crabs were measured (Tables 3-6). Correlation of Carapace length and Carapace width were measured. The value of correlation coefficient $(\mathrm{r}$ ) is 0.848 for Sartoriana spinigera, 0.996 for Sartoriana trilobata, 0.989 for Labothelphusa wood-masoni and 1.00 for Pyxidognathus fluviatilis which implies that there is a strong positive linear association between the variables, carapace length

\begin{tabular}{|l|l|l|l|l|}
\hline \multicolumn{5}{|l|}{ Table 3: Biometric measurements of Sartoriana spinigera. } \\
\hline Measurement & Min. (cm) & Max. $(\mathrm{cm})$ & Mean $(\mathrm{cm})$ & Std. deviation \\
\hline Carapace length & 1.89 & 2.40 & 2.08 & 0.2 \\
\hline Carapace width & 2.50 & 3.28 & 2.77 & 0.29 \\
\hline Abdominal length & 1.25 & 1.75 & 1.48 & 0.17 \\
\hline Telson length & 0.30 & 0.50 & 0.4 & 0.09 \\
\hline Merus length & 0.93 & 1.27 & 1.14 & 0.12 \\
\hline Carpal length & 0.60 & 1.00 & 0.78 & 0.16 \\
\hline Palm length & 1.50 & 2.26 & 1.89 & 0.26 \\
\hline
\end{tabular}

Table 4: Biometric measurements of Sartoriana trilobata

\begin{tabular}{|l|c|c|c|c|}
\hline Measurement & Min. $(\mathrm{cm})$ & Max. $(\mathrm{cm})$ & Mean $(\mathrm{cm})$ & Std. deviation \\
\hline Carapace length & 0.93 & 3.82 & 2.42 & 0.84 \\
\hline Carapace width & 1.14 & 4.88 & 3.1 & 1.083 \\
\hline Abdominal length & 0.68 & 2.89 & 1.75 & 0.66 \\
\hline Telson length & 0.23 & 0.85 & 0.52 & 0.17 \\
\hline Merus length & 0.48 & 2.32 & 1.26 & 0.51 \\
\hline Carpal length & 0.41 & 1.89 & 1.03 & 0.41 \\
\hline Palm length & 0.85 & 3.90 & 2.26 & 0.87 \\
\hline
\end{tabular}

Table 5: Biometric measurements of Labothelphusa wood-masoni.

\begin{tabular}{|c|c|c|c|c|}
\hline Measurement & Min.(cm) & Max.(cm) & Mean(cm) & Std. deviation \\
\hline Carapace length & 1.30 & 3.00 & 2.33 & 0.46 \\
\hline Carapace width & 1.55 & 3.55 & 2.89 & 0.56 \\
\hline Abdominal length & 0.84 & 2.50 & 1.82 & 0.48 \\
\hline Telson length & 0.36 & 1.15 & 0.54 & 0.24 \\
\hline Merus length & 0.55 & 1.13 & 0.97 & 0.17 \\
\hline Carpal length & 0.21 & .96 & .79 & 0.23 \\
\hline Palm length & 0.61 & 2.85 & 2.15 & 0.67 \\
\hline
\end{tabular}

Table 6: Biometric measurements of Pyxidognathus fluviatilis.

\begin{tabular}{|l|l|l|l|l|}
\hline Measurement & Min.(cm) & Max.(cm) & Mean(cm) & Std. deviation \\
\hline Carapace length & 1.90 & 2.10 & 2.00 & 0.14 \\
\hline Carapace width & 2.60 & 2.90 & 2.75 & 0.21 \\
\hline Abdominal length & 1.50 & 1.60 & 1.55 & 0.07 \\
\hline Telson length & 0.25 & 0.30 & 0.28 & 0.04 \\
\hline Merus length & 1.15 & 1.20 & 1.18 & 0.04 \\
\hline Carpal length & 0.50 & 0.60 & 0.55 & 0.07 \\
\hline Palm length & 1.20 & 1.30 & 1.25 & 0.07 \\
\hline
\end{tabular}

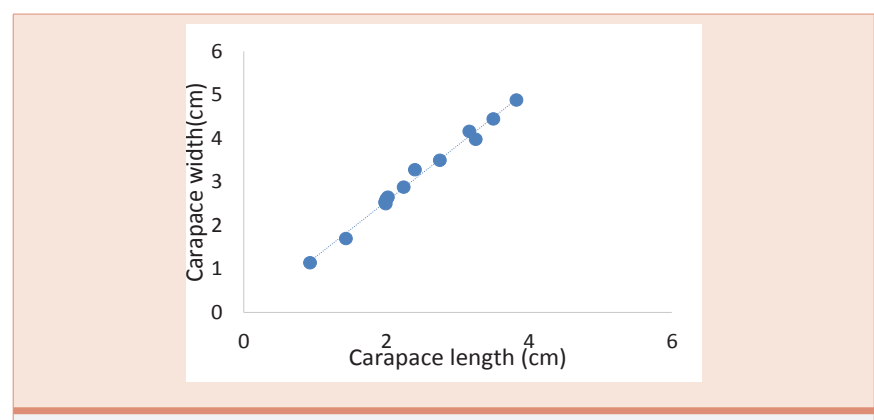

Figure 7: Sartoriana trilobata.

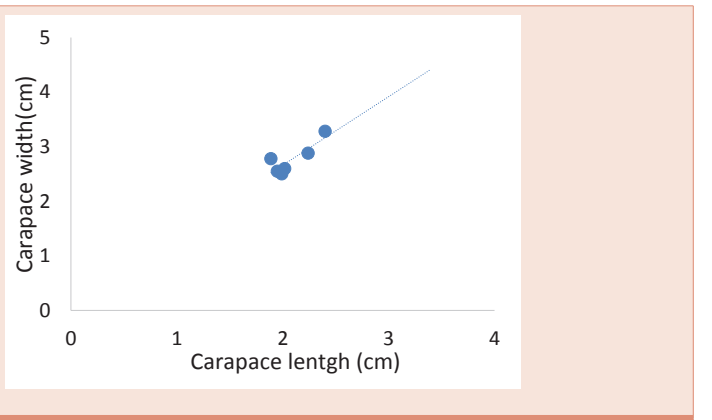

Figure 8: Sartoriana spinigera.

and carapace width (Figures 7-10). Correlation is significant at the 0.05 level (2-tailed) for S.spinigera while 0.01 level (2-tailed) for $S$. trilobata, Labothelphusa wood-masoni and Pyxidognathus fluviatilis.

\section{Conclusion}

There was no sufficient previous information of crabs in hill streams and thus the comparison of the present findings with 

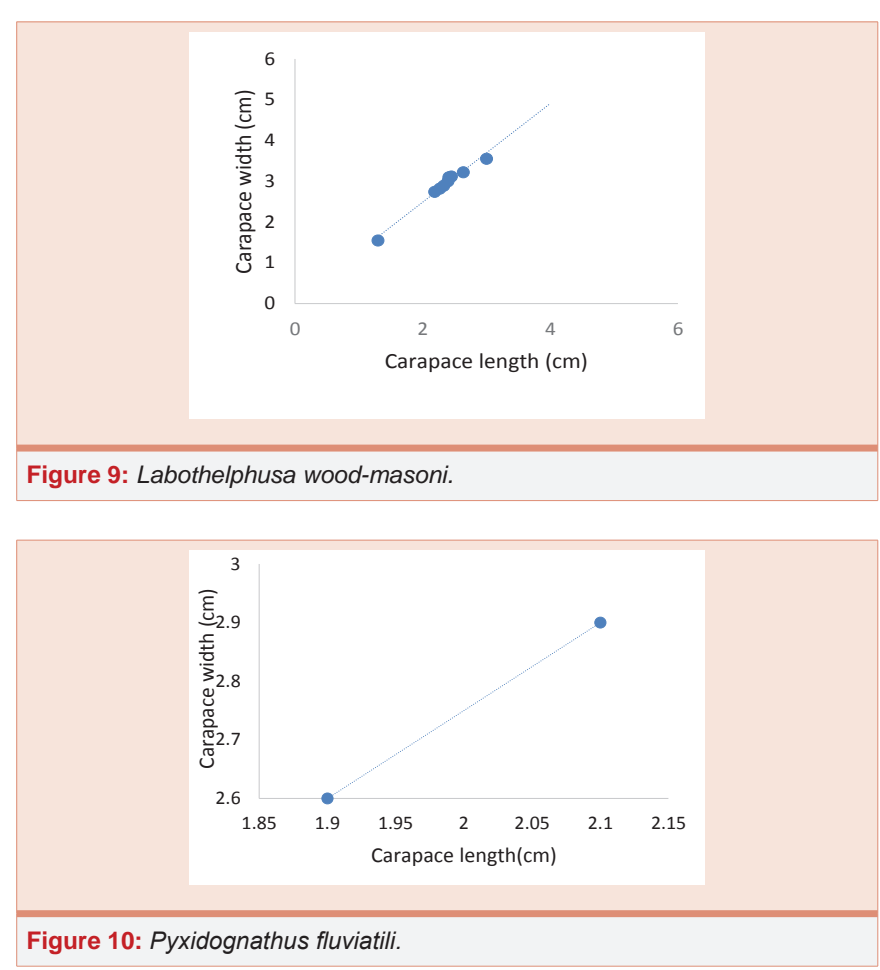

previous one was not possible. Total 4 species of crabs were found in this study. Among the 4 species, Sartoriana trilobata (Alcock, 1909) is an IUCN [9] red listed species and this species is under data deficiency conservation rank. Moreover the present study mainly focused on morphological characteristics and habitats of crab species. The hill streams of Bangladesh are regarded as hot spot of biodiversity and Crabs have enhanced this biodiversity. Moreover, tribal people of Bangladesh depend on crabs for food. The present study signals that the hilly area contains a rich biodiversity which are usually less known than other parts of the country and it strongly suggests the further extensive survey of all hilly districts of Bangladesh by long term basis.

\section{References}

1. Yeo DC, Ng PK, Cumberlidge N, Magalhaes C, Daniels SR, et al. (2008) Global diversity of crabs (Crustacea: Decapoda: Brachyura) in freshwater. Hydrobiologia 595: 275-286.

2. Collen B, Ram M, Dewhurst N, Clausnitzer V, Kalkman VJ, et al. (2009) Broadening the coverage of biodiversity assessments. Wildlife in a Changing World-An Analysis of the 2008 IUCN Red List of Threatened Species, 67.

3. Ingle RW (1983) Shallow water crabs. The Linean Society of London and Estuarine and British water Science Association, Cambridge University press 1-159.

4. Laurent MS (1980) Sur la classification et la phylogénie des Crustacés Décapodes Brachyoures. II. Heterotremata et Thoracotremata Guinot, 1977. Comptes rendus de l'Académie des sciences t. 290: 1317-1320.

5. Alcock A (1900) Materials for a carcinological fauna of India. No. 5.Brachyura Primigenia or Dromiacea. Journal of the Asiatic Society of Bengal, Calcutta 68: 1-104.

6. Cumberlidge N, Sachs R (1989) Zeitschrift Fur Angewandte Zoologie. German Journal For Applied Zoology 220-229.

7. Ahmed ATA, Kabir SMH, Ahmad M, Rahman AKA, Haque EU, et al. (2008) Encyclopedia of Flora and Fauna of Bangladesh, Vol. 18. Part II. Arthropoda: Crustacea. Asiatic Society of Bangladesh, Dhaka. 92-190.

8. Nandi NC, Pramanik SK (1994) Crabs and Crab Fisheries of Sundarban Hindustan Publishing Corporation, Delhi 34-54.

9. Cumberlidge N (2008) Sartoriana trilobata. The IUCN Red List of Threatened Species 2008:e.T134998A4047810. 